Annals of Plant and Soil Research 22(4): 405-409 (2020)

https://doi.org/10.47815/apsr.2020.10012

\title{
Influence of ecological parameters on the incidence aphid population in different potato (Solanum tuberosum L.) cultivars
}

\author{
BIPLAB KAHAR ${ }^{\star}$ AND PALASH MONDAL ${ }^{1}$
}

\author{
Department of Zoology, Panchakot Mahavidyalaya, Purulia-723 121, India
}

Received: July, 2020; Revised accepted: September, 2020

\begin{abstract}
In a field trial, thirteen potato cultivars were evaluated for the incidence of aphids, Myzus persicae (Sulzer) and Aphis gossypii Glover (Aphididae: Hemiptera) during rabi seasons from 2015-2016 to 2017-2018 at District Seed Farm, Department of Agriculture, Burdwan, West Bengal. Results revealed that initiation of aphid population was noticed in the crop field on or before $51^{\text {st }}$ meteorological standard week ( $3^{\text {rd }}$ week of December) with the peak at $7^{\text {th }}$ MSW ( $3^{\text {rd }}$ week of February). However, the level of aphid population was not similar in all the potato cultivars. Though the aphid population in all the cultivars decreased gradually after the peak, the attainment of a higher population differs over the duration. In general, a positive significant correlation of aphid populations was recorded with maximum, minimum temperature, and bright sunshine hours while maximum and minimum humidity had a negative correlation. Stepwise multiple regression analysis revealed that maximum temperature had a significant influence on population fluctuation of aphid. Besides, collective influence (61.8\% to $76.5 \%)$ of all the abiotic factors on the aphid population was also recorded from adjusted $R^{2}$ (0.618 to 0.765$)$ in different potatocultivars.
\end{abstract}

Keywords: potato cultivars, aphid incidence, population fluctuation, weather parameters, correlation, regression

\section{INTRODUCTION}

Potato (Solanum tuberosum L.) plays an important role along with other essential vegetables in our daily diet. It grows all over the country under a wide range of agro-climatic conditions and secures fourth and third rank in the world (Pandey et al.2007) in the area $(2.16 \mathrm{~m}$ ha) and production (53.04 mt), respectively, with the productivity of $24.56 \mathrm{t} \mathrm{ha}^{-1}$ (Indian Horticulture Database, 2019). Varietal limitation along with pest and disease infestations are the major constrains for achieving higher production of potato. Near about 100 insect pests and noninsect pests all over the world were recorded to infest potato crop and of which two species of aphid namely Myzus persicae (Sulzer) and Aphis gossypii Glover (Aphididae: Hemiptera) found to be the most important sucking pest that not onlycausesdamage by sucking plant sap, but also transmitting various potato viruses (Konar et al. 2003, Konar and Paul, 2005, Dharpure, 2002 and Bhatnagar, 2007). A thorough study regarding the incidence pattern of this pest on different resistant or tolerant potato cultivars and effect of prevailing physical environment factors on population fluctuation of the pest is urgently needed (Aheer et al.1994) as they have a profound impact on the survival, development and population build-up of insect pests (Shera et al.2013). The knowledge in this line ultimately helps to formulate effective management strategies against the noxious sucking pests of potato and this was the major reason to focus the present study in this area ofresearch.

\section{MATERIALS AND METHODS}

The experiment was carried out for consecutive three years during rabiseasons from the end of November in 2015-16, 2016-17 and 2017-18 at District Seed Farm $\left(23.2^{\circ} \mathrm{N}\right.$ latitude $87.8^{\circ} \mathrm{E}$ longitudes and $30 \mathrm{~m}$ above mean sea level) of the state department of agriculture, Burdwan, West Bengal. Thirteen potato cultivars viz. $T_{1}=$ Kufri Shailaja, $T_{2}=$ Kufri Khyati, $T_{3}=$ Kufri Sadabahar, $T_{4}=$ Kufri Jyoti, $T_{5}=$ Kufri Himalini, $T_{6}=$ Kufri Pukhraj, $T_{7}=$ Kufri Chipsona-3, $T_{8}=$ Kufri Surya, $\mathrm{T}_{9}=$ Kufri Ashoka, $\mathrm{T}_{10}=$ Kufri Lalima, $\mathrm{T}_{11}=$ Kufri Chipsona 2, $\mathrm{T}_{12}=$ Kufri Chandramukhi and $T_{13}=$ Kufri Atlantic were laid out randomly in a randomized block design with three replications. The dimension of each plot size was $3 \times 4$ sq.m where potato seeds were sown by maintaining the space of $60 \mathrm{~cm}$ row to row and $20 \mathrm{~cm}$ plant to plant Standard agronomic practices 
were followed except for any pesticide application. In all the plots, the crop was dehaulmed 10 days before final harvesting $\left(2^{\text {nd }}\right.$ week of March). Observations on the incidence of aphids in different potato cultivars was recorded at weekly intervals starting from three weeks after sowing to dehaulming of the crop following 100-leaf index method (Simpson, 1940) with slight modification. The data on aphid populations were recorded on 30 compound leaves each from the upper, middle, and lower canopy of 10 plants selected at random in each plot. The mean population data obtained from different potato cultivars were subjected to simple correlation and multiple regression analyses (Gomez and Gomez, 1984) using SPSS software (16.0 version) with meteorological parameters viz. maximum and minimum temperatures $\left({ }^{\circ} \mathrm{C}\right)$, maximum and minimum humidity (\%), rainfall $(\mathrm{mm})$ and bright sunshine $(h)$, obtained from the Department of Agrometeorology, Burdwan.

\section{RESULTS AND DISCUSSION}

\section{Seasonal incidence ofaphid}

Results on the pooled data of three years revealed that initiation of aphid infestation in the crop field was occurred on or before $51^{\text {st }}$ meteorological standard week (MSW) in December and remained active throughout the cropping season at varying population density in different potato cultivars (Fig. 1). The population attained its peak varied from 113.7 to 1127.6 aphids/30 compound leaves during the vegetative stage of crop growth at $7 \mathrm{MSW}\left(3^{\text {rd }}\right.$ week of February) (Table 1) after which the aphid population decreased gradually in all the potato cultivars (Fig. 1). Again, a perusal of Table 1 revealed that aphid population was remained at a higher level in the majority of cultivars before dehaulming at $9 \mathrm{MSW}$ and the level of insect population range varied greatly throughout the crop growing seasons. Attainment of a higher population of insects persisted for a longer period in some cultivars. The cultivars Kufri Atlantic, Kufri Ashoka, Kufri Lalima, Kufri Jyoti, Kufri Chipsona-2, and Kufri Himalini supported the higher pest population, whereas, Kufri Khyati, Kufri Surya, Kufri Chandramukhi, Kufri Shailaja, and Kufri Sadabahar maintained a moderate level of the pest population. The low level of aphid incidence recorded in Kufri Pukhraj and Kufri Chipsona-3 might be due to morphological characters such as narrow, rough, coarse, and smaller leaves than the other cultivars (Konar and Paul, 2006). Besides, the taller height of the plants of these cultivars might pose an unfavorable microclimatic condition within the crop canopy as the pest population was recorded positively correlated with temperature and negatively correlated with the relative humidity during rabiseason (Bhatnagar et al. 2012). It has been also observed that unlike upper leaves, bottom leaves of the most cultivars maintained the higher aphid population suggesting aphids might have marked preference for senescing leaves under shady conditions. Konar and Singh (2009) also reported that Kufri Chandramukhi was susceptible to aphids. On the other hand, Kufri Jyoti and Kufri Jawhar were tolerant but both Kufri chipsona-1 and Kufri chipsona-2 proved resistant to thepest.

Table 1: Population dynamics of aphid during the potato crop growing seasons (Pooled of three years)

\begin{tabular}{|c|c|c|c|c|c|c|c|c|c|c|c|c|c|}
\hline \multirow{2}{*}{ Parameters } & \multicolumn{13}{|c|}{ No. of aphids $/ 30$ compound leaves } \\
\hline & $\mathrm{T}_{1}$ & $\mathrm{~T}_{2}$ & $\mathrm{~T}_{3}$ & $\mathrm{~T}_{4}$ & $\mathrm{~T}_{5}$ & $\mathrm{~T}_{6}$ & $\mathrm{~T}_{7}$ & $\mathrm{~T}_{8}$ & $\mathrm{~T}_{9}$ & $T_{10}$ & $T_{11}$ & $T_{12}$ & $T_{13}$ \\
\hline & $\begin{array}{c}0.3 \\
(51)\end{array}$ & $\begin{array}{c}1.6 \\
(51)\end{array}$ & $\begin{array}{c}3.0 \\
(52)\end{array}$ & $\begin{array}{c}6.4 \\
(51)\end{array}$ & $\begin{array}{l}2.6 \\
(51)\end{array}$ & $\begin{array}{c}0.3 \\
(51)\end{array}$ & $\begin{array}{c}0.3 \\
(51)\end{array}$ & & & $\begin{array}{c}7.3 \\
(51)\end{array}$ & $\begin{array}{c}3.6 \\
(51)\end{array}$ & & \\
\hline & & & & & $\begin{array}{c}738.1 \\
(7)\end{array}$ & & $\begin{array}{c}146.3 \\
(7)\end{array}$ & & & & 8 & & \\
\hline & $\begin{array}{c}179.9 \\
\text { (9) }\end{array}$ & 311.6 & 140.4 & & $\begin{array}{c}404.0 \\
(9)\end{array}$ & 66.3 & $\begin{array}{c}68.9 \\
(9)\end{array}$ & & & & $\begin{array}{c}460.9 \\
\text { (9) }\end{array}$ & $\begin{array}{c}284.9 \\
\text { (9) }\end{array}$ & $\begin{array}{c}603.1 \\
(9)\end{array}$ \\
\hline Pop & $\begin{array}{c}0.3- \\
360.0\end{array}$ & $\begin{array}{c}1.6- \\
650.7\end{array}$ & $\begin{array}{c}3.0- \\
296.8\end{array}$ & $\begin{array}{c}6.4- \\
801.7\end{array}$ & $\begin{array}{c}2.6- \\
738.1\end{array}$ & $\begin{array}{c}0.3- \\
113.7\end{array}$ & $\begin{array}{c}0.3- \\
146.3\end{array}$ & $\begin{array}{c}0.6- \\
556.8\end{array}$ & & $\begin{array}{l}7.3- \\
820.0\end{array}$ & $\begin{array}{c}3.6- \\
787.5\end{array}$ & & \\
\hline $\begin{array}{l}\text { ttainment o } \\
\text { max. } \\
\text { population }\end{array}$ & $\begin{array}{c}259.6- \\
266.1 \\
(6-8)\end{array}$ & $\begin{array}{c}310.7- \\
311.6 \\
(5-9)\end{array}$ & $\begin{array}{c}212.5- \\
256.5 \\
(6-8)\end{array}$ & $\begin{array}{c}271.7- \\
510.3 \\
(4-9)\end{array}$ & $\begin{array}{c}203.3- \\
404.0 \\
(4-9)\end{array}$ & $\begin{array}{c}113.7 \\
(7)\end{array}$ & $\begin{array}{c}146.3 \\
(7)\end{array}$ & $\begin{array}{c}293.3- \\
296.0 \\
(5-9)\end{array}$ & $\begin{array}{l}231.3- \\
566.7 \\
(3-9)\end{array}$ & $\begin{array}{c}206.0- \\
503.1 \\
(3-9)\end{array}$ & $\begin{array}{c}232.7- \\
460.9 \\
(4-9)\end{array}$ & $\begin{array}{c}313.7- \\
284.9 \\
(5-9)\end{array}$ & $\begin{array}{c}236.6- \\
603.1 \\
(3-9)\end{array}$ \\
\hline
\end{tabular}

$T_{1}:$ K. Shailaja; $T_{2}: K$. Khyati; $T_{3}: K$. Sadabahar; $T_{4}: K$. Jyoti; $T_{5}: K$. Himalini; $T_{6}: K$. Pukhraj; $T_{7}: K$. Chipsona-3; $T_{8}: K$. Surya; $T_{g}:$ K. Ashoka; $T^{10}:$ K. Lalima; $T_{11}:$ K Chipsona-2; $T_{12}:$ K. Chandramukhi; $T_{13}:$ K. Atlantic

Data in parentheses indicate meteorological standard week 


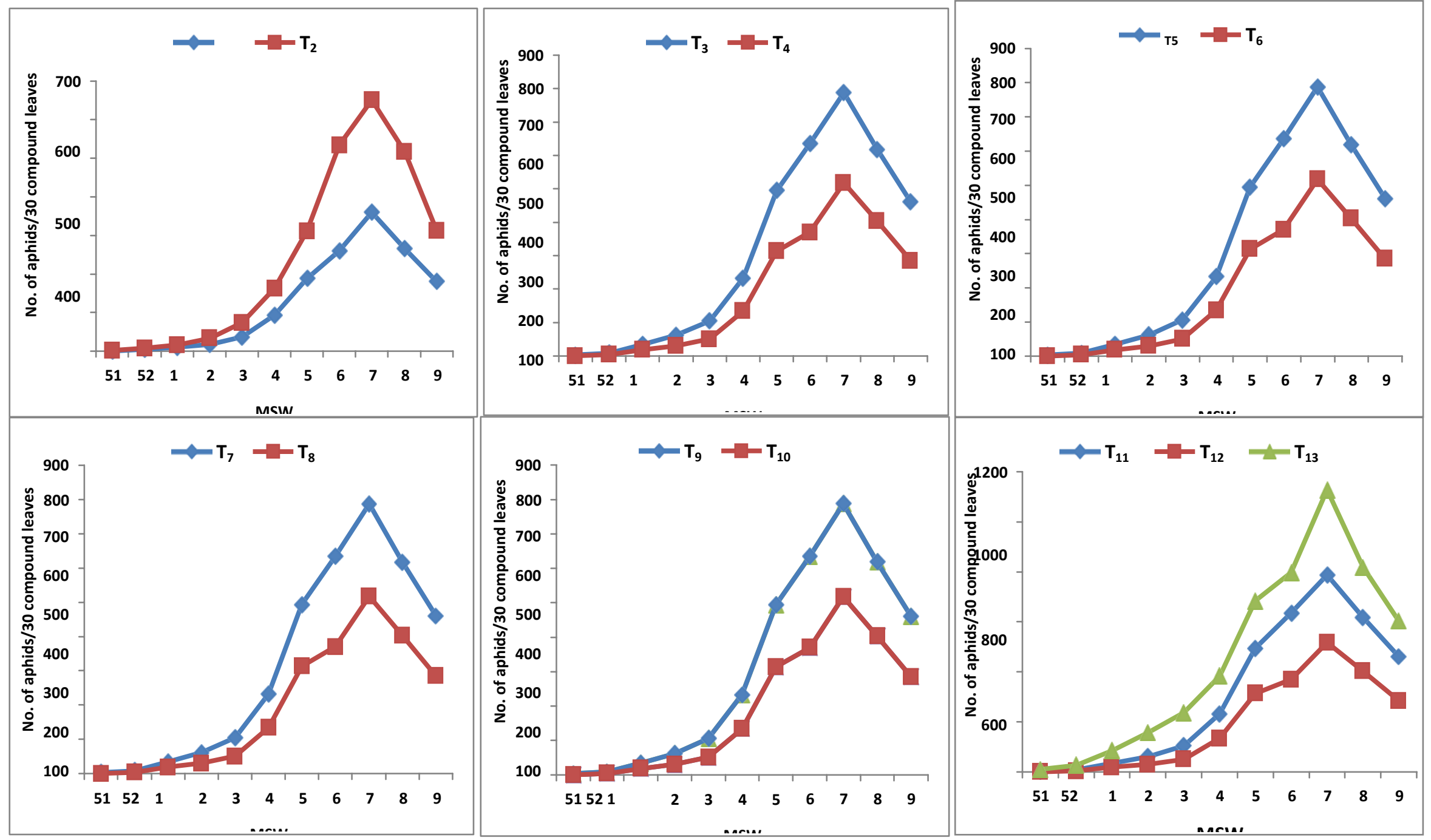

Fig.1: Population fluctuation of aphid in cultivars of potato ( $T_{1}$ to $\left.T_{13}\right)$ during the different meteorological standard weeks (MSW) of crop growing seasons 
Table 2: Correlation coefficients between abiotic factors and aphid population in potato cultivars (Pooled of three years)

\begin{tabular}{|c|c|c|c|c|c|c|c|c|c|c|c|c|c|}
\hline \multirow{2}{*}{$\begin{array}{c}\text { Weather } \\
\text { parameters }\end{array}$} & \multicolumn{13}{|c|}{ Potato cultivars } \\
\hline & $\mathrm{T}_{1}$ & $T_{2}$ & $T_{3}$ & $\mathrm{~T}_{4}$ & $T_{5}$ & $\mathrm{~T}_{6}$ & $\mathrm{~T}_{7}$ & $\mathrm{~T}_{8}$ & $\mathrm{~T}_{9}$ & $T_{10}$ & $T_{11}$ & $T_{12}$ & $T_{13}$ \\
\hline $\operatorname{Tmax}\left({ }^{0} \mathrm{C}\right)$ & $0.84^{\star *}$ & $0.83^{\star \star}$ & $0.85^{\star \star}$ & $0.84^{\star \star}$ & $0.85^{\star *}$ & $0.88^{* *}$ & $0.87^{\star \star}$ & $0.86^{* *}$ & $0.81^{* *}$ & $0.82^{* \star}$ & $0.86^{\star \star}$ & $0.86^{* \star}$ & $0.82^{\star \star}$ \\
\hline $\mathrm{T} \min \left({ }^{0} \mathrm{C}\right)$ & $0.79^{* *}$ & $0.78^{\star \star}$ & $0.81^{* *}$ & $0.75^{\star \star}$ & $0.80^{\star *}$ & $0.83^{* *}$ & $0.83^{* *}$ & $0.81^{*}$ & $0.73^{*}$ & $0.73^{*}$ & $0.78^{* *}$ & O & $0.74^{* *}$ \\
\hline $\begin{array}{c}\text { Tgradient } \\
\left({ }^{\circ} \mathrm{C}\right)\end{array}$ & $0.66^{*}$ & $0.63^{*}$ & $0.62^{*}$ & $0.73^{* \star}$ & $0.67^{*}$ & $0.69^{*}$ & $0.65^{*}$ & $0.67^{*}$ & $0.68^{*}$ & $0.73^{*}$ & $0.71^{*}$ & $0.64^{*}$ & $0.69^{*}$ \\
\hline $\mathrm{RH} \max (\%)$ & -0.44 & -0.45 & 0.49 & -0.46 & -0.45 & -0.47 & -0.44 & -0.44 & -0.42 & -0.46 & -0.46 & -0.44 & -0.44 \\
\hline $\mathrm{RHn}$ & -0.05 & -0.05 & -0.08 & -0.12 & -0.06 & -0.07 & -0.03 & -0.0 & -0.11 & -0.14 & -0.10 & -0.05 & -0.12 \\
\hline$B S$ & $0.75^{\star *}$ & $0.74^{\star \star}$ & $0.74^{\star *}$ & $0.79^{* \star}$ & $0.76^{* *}$ & $0.75^{* *}$ & $0.73^{\star \star}$ & $0.74^{* *}$ & $0.75^{\star *}$ & $0.78^{\star \star}$ & $0.78^{* *}$ & $0.74^{\star *}$ & $0.75^{* *}$ \\
\hline Rain (mm) & 0.21 & 0.19 & 0.19 & 0.15 & 0.18 & 0.18 & 0.22 & 0.20 & 0.23 & 0.16 & 0.15 & 0.24 & 0.22 \\
\hline
\end{tabular}

\section{Impact of abioticfactors}

Results on correlation analysis between aphid population and abiotic factors showed that the pest population was not affected by a single abiotic factor, rather more than one factor was responsible for the population build-up of aphid during the crop growing seasons. A perusal of Table 2 revealed that the pest population was positively correlated with maximum $\left(\mathrm{T}_{\max }\right)$ and minimum temperature $\left(T_{\min }\right)$, temperature gradient, and bright sunshine hours (BSS) of which $\left(T_{\max }\right)$ and BSS had a significant effect on population fluctuation of the pest. Whereas, both maximum and minimum relative humidity showed a negative correlation in all the cultivars. These findings are more or less in conformity with the findings of Konar and Paul (2006) who reported that aphid population on potato crop was positively correlated with temperature, rainfall and sunshine hours, but negatively correlated with relative humidity. The understanding of the abiotic factors affecting the population of the insect pest is a prerequisite for planning an effective and more precise management strategy for a particular pest. Nowadays, a lot of works are going on to evolve elaborate procedures and models for identifying the key factors dominating the abundance and distribution of insect pests. Developing weatherbased models of population phenology can enhance decision-making processes around pest control and provide greater opportunity to control the pest within integrated pest management programs (Damos and Soultani, 2010).Hence, the cumulative effect of the ecological parameters was worked out by multiple regression analysis for consecutive three years (2015-16, 2016-17, and 2017-18) and pooled (Table 3 ). The regression model (predicted regression equation) gave a comprehensive picture of the relationship between pest population and ecological parameters.Stepwise regression analysis

Table 3: Stepwise multiple regression analyses of ecological ameters vs aphid population in potato cultivars (Pooled of threeyears)

\begin{tabular}{|c|c|c|c|}
\hline Potato cultivars & Prediction equation & Adjusted $\mathrm{R}^{2}$ & Significant forStandardized coefficients \\
\hline $\mathrm{T}_{1}$ & $\mathrm{Y}=-437.020+21.963 \mathrm{X}_{1}$ & $0.687^{*}$ & $\mathrm{p}=0.001$ \\
$\mathrm{~T}_{2}$ & $\mathrm{Y}=-809.698+40.666 \mathrm{X}_{1}$ & $0.663^{*}$ & $\mathrm{p}=0.001$ \\
$\mathrm{~T}_{3}$ & $\mathrm{Y}=-382.784+18.992 \mathrm{X}_{1}$ & $0.693^{*}$ & $\mathrm{p}=0.001$ \\
$\mathrm{~T}_{4}$ & $\mathrm{Y}=-938.882+49.545 \mathrm{X}_{1}$ & $0.691^{*}$ & $\mathrm{p}=0.001$ \\
$\mathrm{~T}_{5}$ & $\mathrm{Y}=-930.872+46.968 \mathrm{X}_{1}$ & $0.707^{*}$ & $\mathrm{p}=0.001$ \\
$\mathrm{~T}_{6}$ & $\mathrm{Y}=-301.865+14.879 \mathrm{X}_{1}$ & $0.765^{*}$ & $\mathrm{p}=0.001$ \\
$\mathrm{~T}_{7}$ & $\mathrm{Y}=-171.569+8.470 \mathrm{X}_{1}$ & $0.737^{*}$ & $\mathrm{p}=0.001$ \\
$\mathrm{~T}_{8}$ & $\mathrm{Y}=-705.346+35.239 \mathrm{X}_{1}$ & $0.718^{*}$ & $\mathrm{p}=0.001$ \\
$\mathrm{~T}_{9}$ & $\mathrm{Y}=-1072.966+57.811 \mathrm{X}_{1}$ & $0.618^{*}$ & $\mathrm{p}=0.003$ \\
$\mathrm{~T}_{10}$ & $\mathrm{Y}=-908.654+48.970 \mathrm{X}_{1}$ & $0.652^{*}$ & $\mathrm{p}=0.002$ \\
$\mathrm{~T}_{11}$ & $\mathrm{Y}=-1001.396+51.019 \mathrm{X}_{1}$ & $0.715^{*}$ & $\mathrm{p}=0.001$ \\
$\mathrm{~T}_{12}$ & $\mathrm{Y}=-268.896+13.388 \mathrm{X}_{1}$ & $0.713^{*}$ & $\mathrm{p}=0.001$ \\
$\mathrm{~T}_{13}$ & $\mathrm{Y}=-1179.393+63.178 \mathrm{X}_{1}$ & $0.645^{*}$ & $\mathrm{p}=0.002$ \\
\hline
\end{tabular}

Y: Aphid population (Dependent variable); $X_{1}=$ Max.Temp. $\left({ }^{\circ} \mathrm{C}\right), X_{2}=$ Min. Temp. ${ }^{\circ} \mathrm{C}$ ), $X_{4}=$ Max. Humidity (\%), $X_{5}=$ Min. Humidity (\%), $X_{6}=$ Sunshine (h), $X_{7}=$ Rainfall $(\mathrm{mm})$, Excluded variables: $X_{2}, X_{3}, X_{4}, X_{5}, X_{6}, X_{7}$, ${ }^{*}$ Significant at $p=0.05$ 
was followed to drop the least significant factors in a stepwise manner and finally to find out the best effective predictive model. In the predictive model (regression equation) most of the ecological parameters except the maximum temperature were excluded. This finding suggested that maximum temperature played the most significant role in the fluctuation of the aphid population. Findings of the regression equations were adjudged by the significance test of the coefficient of determination $\left(R^{2}\right)$ and the parameter was further adjusted to calculate the more precise value using Adjusted $R^{2}$ which reflected the combined effect of all the ecological parameters on population abundance of aphid in the crop field during the crop growing seasons. The Adjusted $R^{2}$ values in different cultivars were varied from 0.618 to 0.765 which indicated that the combined effect of all the ecological parameters onthePopulation fluctuation of aphids was ranged between 61.8 to $76.5 \%$ and proved significant at $p=0.05$.

\section{REFERENCES}

Aheer, G. M., Ahmad, K. J. and Ali, A. (1994) Role of weather in fluctuating aphid density in wheat crop. Journal of Agriculture Research 32: 295-301.

Bhatnagar, A. (2007) Incidence and succession of thrips, leafhopper and whitefly in combination of planting dates and potato varieties.Annals of Plant Protection Science 15:101-105.

Bhatnagar, A., Somani, A.K. and Chander, S. (2012) Build up of Myzus persicae and development of mosaics on potato in central India. Potato Journal 39: 208-210.

Damos, P.T. and Soultani, M.S. (2010) Development and statistical evaluation of models in forecasting moth phenology of major lepidopterous peach pest complex for Integrated Pest Management programs. Crop Protection 29:1190-1199.

Dharpure, S.R. (2002) Changing scenario of insect pests of potato in Satpura plateau of Madhya Pradesh.Journal of Potato 99:135138

Gomez, K.A. and Gomez, A.A. (1984) Data that violate some assumption of the analysis of variance In: Statistical Procedures for Agricultural Research. A Wiley-Interscience Publication, USA pp. 296-309.

Indian Horticulture Database (2019) Ministry of Agriculture, Govt. of India 85, Instit.Area, Sector - 18, Gurgaon - 122015.

Konar, A. and Paul, S. (2005) Efficacy of some granular insecticides and pesticides against
The infestation of aphid showed a great sensibility to weather variations occurring over the period studied. The establishment of significant positive correlations of aphid population with temperature and bright sunshine hours indicated that when the temperature rose during February the infestation was increased gradually. Again, the overall response of ecological parameters on population fluctuation of pest is dependent on the impact of climate change, host plant characters host, and some other factors. Linear regression analysis revealed that measured environmental variables have a significant effect on the insect pest densities $(P=0.05)$ confirming the results of correlation analysis. After validating the individual seasonal data, these types of information can be used to prepare a better forecasting model and thereby formulating effective management strategies forthis pest.

mole cricket on potato. Journal of Applied Zoological Researches 16: 59-60.

Konar, A. and Paul, S. (2006) Influence of abiotic factors on the occurrence of virus vectors on potato in plains of West Bengal.Journal of Entomological Research 30: 1-6.

Konar, A. and Singh, N.J. (2009) Occurrence of aphid on various potato germplasms in eastern gangetic plains of West Bengal. The Journal of Plant Protection Science 1:21-24.

Konar, A., Paul, S. and Chettri, M. (2003) Efficacy of synthetic insecticides, biopesticides and azadirachtin against aphids on potato in West Bengal. Abstract of the National Sympoisium on "Assessment and Management of Bioresources", University of North Bengal, Darjeeling, West Bengal, India pp.30.

Pandey, R., Rai, M.K., Sharma, K. and Chaudhari, D. (2007) Studies on population dynamics of Myzus persicae on potato crop with special reference to its relation with various weather parameters. Vegetable Science 34(2): 167-169.

Shera, P.S., Kumar, V. and Aneja, A. (2013) Seasonal Abundance of Sucking Insect Pests on Transgenic Bt Cotton vis-à-vis Weather Parameters in Punjab, India. Acta Phytopathologica et Entomologica Hungarica 48 (1), pp.63-74.

Simpson, G.W. (1940) Aphid and their relation to the field transmission of potato viral diseases in north-east Maine. Maine Agricultural Experiment-Statistical Bulletin, pp. 550-605. 